\title{
Creativity Moves Ahead: Creative Learning Elements in Higher Education. The ML-LL Approach
}

\author{
Birgit Oberer \\ Kadir Has University Istanbul, Turkey \\ journal@etcop.com
}

\begin{abstract}
Being creative is an always communicated need in the business environment and nowadays it is increasingly emphasized in education. Educators have to develop creative structures in education, teach students how to be(come) creative, and they need to support them in using their knowledge on creativity during their student life and later on in their business life. To be able to integrate creativity elements in education educators could focus on several creative elements. In this study two different categories of creative education elements were integrated, which were mobile learning modules and Lego learning modules. The results of this study revealed that the integration of mobile learning modules and Lego learning modules could improve student performance in terms of participation, project quality, and the overall course result.
\end{abstract}

Keywords: Mobile learning, creative education, course design

\section{Introduction}

Creativity is a keyword in today's education. 'Be creative! Be innovative! Then you can be successful!' That's what students nowadays hear in the courses they attend. Being creative is shown as a guarantee for success. But what does it mean 'to be creative'? What makes a person creative? Do we have different degrees of creativity? $[10,11,12]$. Which degree is at least needed to be successful? How can we measure creativity in general and students' creativity in working with course related topics in particular? All of these are questions of interest when educators want to make their students creative $[6,8,9]$. Mobile learning refers to the possibilities of accessing learning content at multiple locations, with different devices; and can be used to enhance the learning situations for students. Nowadays, students as well as educators have to deal with the complexity of courseware on mobile devices $[5,6,7,8,13]$. In this study we focus on integration mobile learning modules as well as Lego learning modules into a bachelor's degree course on management information systems (MIS) in order to see if they are able to increase student performance.

\section{Previous Studies}

\subsection{Mobile learning modules in higher education}

In a previous study [1] we developed a course concept for a bachelor's degree course on geographic information systems (GIS) integrating mobile learning modules in higher education. The course was designed for students from different faculties and used 12 out of 
14 weeks on mobile learning modules (MLM) as supplements to traditional learning methods, such as a lecture, student project, or field analysis.

Before integrating MLM in the course design, the students' performance was sufficient with about $80 \%$ of all students achieving a grade of BB or higher. Nevertheless, there was a need for improving the teaching methods for the course because the performance in courses that the GIS course was a prerequisite of was generally insufficient. Students obtained basic knowledge on geographic information systems but had no idea how to apply this knowledge and then use it for other courses.

For the mobile learning modules, mobile devices, such as mobile phones or tables, can be used. For the course, of which the design was enriched with MLM, all students were given tables to work on their MLM during the course. The MLM were divided into group projects and individual assignments. A sample student project was on GIS cartography and map production, where students used their tablets to find sample applications for map production in order to prepare a base map on their own and to share their project results with the instructor.

To communicate within student groups and for instructor-student and instructor-student group communication, the instructor opened a group on Google Plus. Students obtained a basic introduction on the main features of Google Plus. Circles were created for the whole course and single groups of students, working on different projects. Sparks were used to share research results with circles, selected students, or the whole course. Hangouts were used as online office hours [2].

At the end of the course, an evaluation showed that $97 \%$ of all students used their tablet frequently to be active on Google Plus, to communicate with classmates, share research results, or communicate with the instructor. This high value of activeness on social networks was expected but it has to be mentioned that $40 \%$ of all students who were active on social media during the course did not use these media before joining the course. $70 \%$ of all groups used huddles for group chat; all groups used a hangout for group internal videoconferencing. More than $50 \%$ of all students indicated their use of Google Plus for upcoming courses as well. To sum up, compared to the results before MLM integration, students worked more interactively, learned how to use mobile devices for course issues, worked on different GIS applications actively, and prepared their course project using their tablets.

\subsection{Lego learning modules in higher education}

In another previous study [3], we designed and implemented a course design for a management information management (MIS) course, focusing on management and organization, integrating Lego learning modules (LLM), one creative teaching element, in teaching and student learning.

This course was intended for master's degree students for a university's social science institute, mainly with an engineering education. Similar to the course integrated in the study explained before, student performance for the course was sufficient, with less than $10 \%$ of all students failing in recent years, and the knowledge generated in this course could not be transferred to other courses that this one is a prerequisite of. The instructor structured the course without any student project or active assignment, focusing only on a performance evaluation in the midterm and final exam.

To improve the course results and increase student participation, the instructor changed the course design, in adopting the course structure, teaching methods by including creative education elements. The instructor has chosen Lego Serious Play as the creative education element to be focused on in the course to be improved. Lego bricks offer a simple and innovative method for people to communicate, express their opinion, feelings and attitudes, 
and needs no further training to be used. Lego Serious Play (LSP) could be used for strategic management, problem solving, decision making, engineering, helping people with a simple 'language' to communicate with each other [4].

Students worked on their Lego learning modules (LLM) in the classroom, in their group projects, or for individual assignments. Students were given a sample company, for which the strategic management framework had to be built using LLM among other methods. LLM was used for defining organizational goals, building organizational designs, developing a decision making process, working on leadership issues, developing problem solving strategies, and working on communication issues for the sample company.

The first student evaluation was done in 2013, focusing on the dimensions student, participation, quality and grade, measuring the quality of student projects, the student satisfaction index, attendance rate, and the overall course results. In all four categories, the student performance could be improved significantly, with improving the overall course result from 0.76 before LLM integration to 0.89 after Lego learning modules have been integrated.

\section{Case Study on Integrating Creative Education elements in the course design: The ML-LL Approach}

After conducting the two studies mentioned in 3.1 and 3.2, a new challenge for improving the course design, teaching methods, and student performance focused on how to combine mobile learning modules and Lego learning modules to achieve an even better course performance. A case study was conducted in the spring term 2013 involving the creation of a course design integration mobile learning modules and Lego learning modules, finding out their interdependences, and defining an optimal level of integration of both learning modules.

The mobile learning - Lego learning (ML-LL) approach focuses on the target to integrate both types of learning modules in one course design (Figure 1).

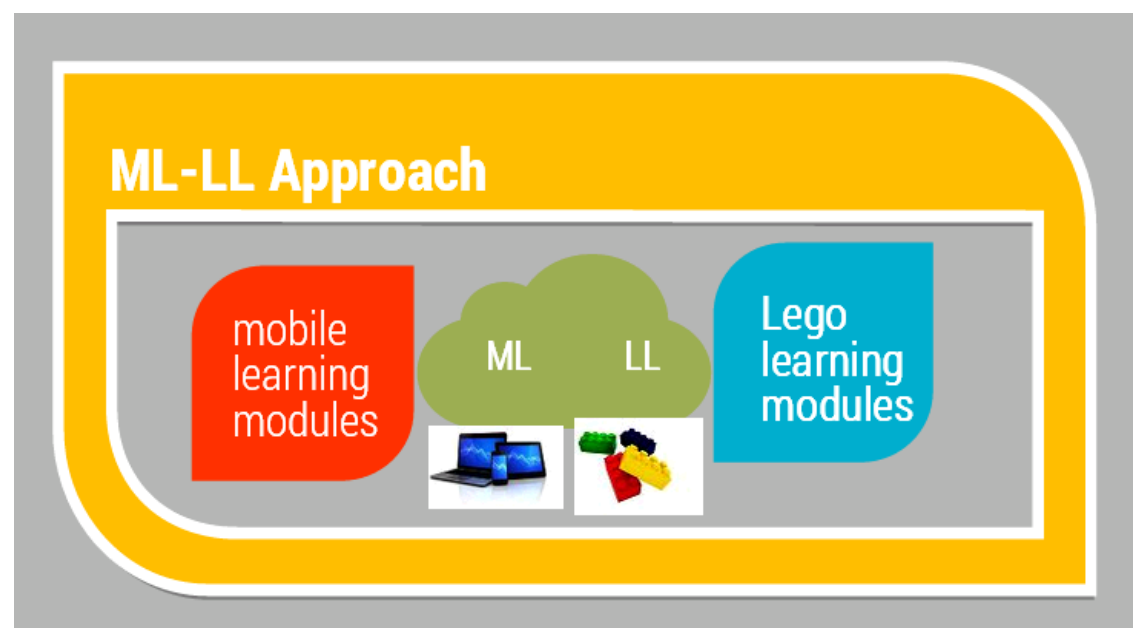

Figure 1. The ML-LL approach

The sample course that was chosen to be improved was the 'Enterprise Information Systems' (EIS) course from a university's Management Information Systems (MIS) bachelor's degree program. The course is mandatory for fourth year students from the MIS bachelor's degree program and an elective for second to fourth year students of other departments and faculties. Table 1 shows the topics covered by the EIS course. 


\section{Table 1. 'Enterprise Information Systems' topics}

\begin{tabular}{|c|c|}
\hline Week & Topic \\
\hline $1-2$ & Enterprises and their information systems \\
\hline $3-4$ & Strategic planning \\
\hline $5-6$ & Production planning \\
\hline $7-8$ & Demand management \\
\hline $9-10$ & Distribution management \\
\hline $11-14$ & $\begin{array}{l}\text { Group projects } \\
\text { Selected topics }\end{array}$ \\
\hline
\end{tabular}

To work on the course topics, students were given a sample company, the EIS Ltd. This fictitious company, which was founded in 1984, is located in Germany and offers services for the design and supply of production plants for glass wool. The company's customers are located in Europe, Russia, and India mainly. EIS Ltd. is specialized in offering technical solutions and tailored engineering for their customers, and cooperates with partners around the world to guarantee the timeliness and quality of its customers. Table 2 gives an overview on the company's services. These services are directly related to the topics to be covered in the EIS course and the students' assignments on ML and LL.

Table 2. Services offered by EIS Ltd.

\begin{tabular}{|l|l|}
\hline \multicolumn{2}{|c|}{ EIS Ltd. } \\
\hline \multicolumn{2}{|c|}{$\begin{array}{l}\text { Enterprise Information Systems } \\
\text { Bachelor's Degree, Sample Company }\end{array}$} \\
\hline No. & Service \\
\hline 1 & Project planning \\
\hline 2 & Construction and installation \\
\hline 3 & Design of parts \\
\hline 4 & Division of work \\
\hline 5 & Mechanical construction \\
\hline 6 & Electrical installation \\
\hline 7 & Construction management \\
\hline 8 & Technical assistance \\
\hline 9 & Customer training \\
\hline
\end{tabular}

In the EIS course in week 1 and 2, a general introduction on enterprise information systems is given, followed by strategic planning issues in week 3 and 4 . For the strategic planning, the EIS Ltd., the course's sample company, is used to work on strategic planning issues. Selected topics to be considered within the strategic planning process are summarized in table 3, with the corresponding mobile learning (ML) modules and Lego learning (LL) modules. Strategic management covers (1) organizational design, (2) team management, (3) project management, (4) change management, (5) IT management, and (6) network management. To define ML modules the main question to be answered is: 'How can mobile devices (mobile phone, laptop, tablet) be used to work on course related topics?' Similar to the strategic planning process the instructor defined topics and related ML modules and LL modules for 
the other course topics (production planning, demand management, and distribution management) as well. Figure 2 shows the relationship between the ML modules and the LL modules for team management, as part of the strategic planning topic for the sample company EIS Ltd.

Generally, students worked in teams of no more than five; all groups had to present their results regularly to the instructor and the other groups.

For the mobile learning modules, students were given an introduction to Google Plus and they used its functionalities (handouts, sparks, huddles) throughout the course, for office hours with the instructor, explaining assignments, communicating within the group, with other groups or the instructor, for sharing course related materials, for chatting with each other and videoconferencing with multiple users.

For the Lego learning modules, students were given an introduction to the Lego Serious Play (LSP) methodology and a sample workshop (2 hours at the beginning of the course) was organized by the instructor. The moderator of the workshop was a certified local LSP moderator. Within this workshop, students had to design their current situation as a student at a university with the Lego bricks. Everyone was given a few minutes to explain his or her model and the five best ideas presented received an award by the dean, which was a certificate for creative work with LSP.

To work with Lego Serious Play for their LL modules, every student was given a Lego Serious Play starter kit, containing a selection of standard Lego bricks combined with Lego Dublo elements, which should be sufficient for students to build metaphors, participate in creative storytelling and to apply imagination. Some results of the projects that students worked on are summarized in Figure 3 and Table 4.

Table 3. EIS course topics and the ML-LL approach

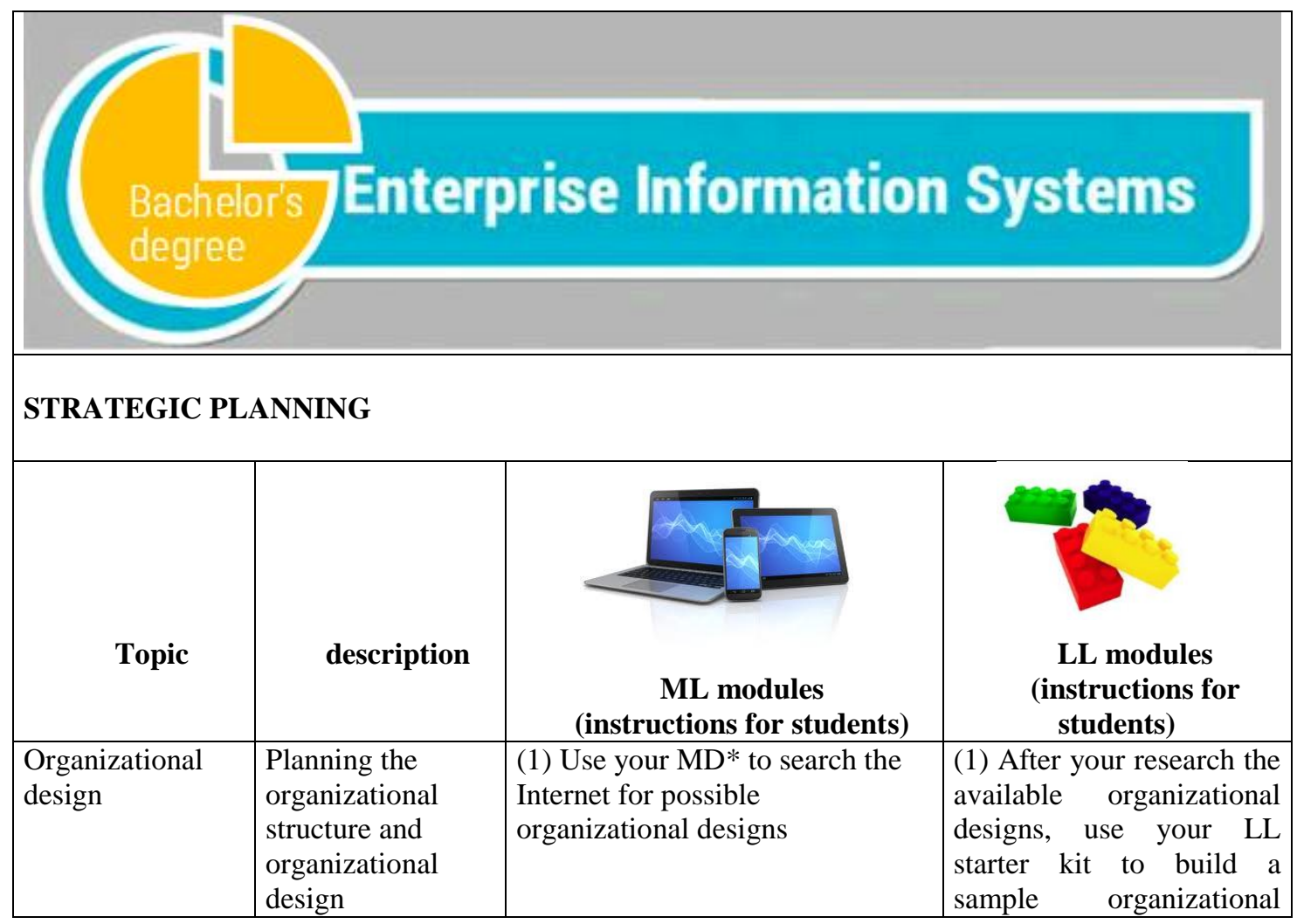




\begin{tabular}{|c|c|c|c|}
\hline & & $\begin{array}{l}\text { (2) After you finished LL } \\
\text { modules (1), use your MD to } \\
\text { design the organizational } \\
\text { structure of EIS Ltd.: } \\
\mathrm{Q}^{* *} \text { : Do you know which } \\
\text { software tools to use? Conduct } \\
\text { some research and choose one } \\
\text { software tool to design the } \\
\text { organizational structure. }\end{array}$ & $\begin{array}{l}\text { design for EIS Ltd. Share } \\
\text { your results with your } \\
\text { colleagues in your group, } \\
\text { decide on which proposal } \\
\text { should be presented to the } \\
\text { instructor (as a result of } \\
\text { the whole group) or if } \\
\text { possible and necessary, } \\
\text { combine different designs } \\
\text { to one and present it to the } \\
\text { instructor. }\end{array}$ \\
\hline $\begin{array}{l}\text { Team } \\
\text { management }\end{array}$ & $\begin{array}{l}\text { Based on the } \\
\text { chosen } \\
\text { organizational } \\
\text { design the team } \\
\text { management } \\
\text { process has to be } \\
\text { planned and } \\
\text { implemented }\end{array}$ & $\begin{array}{l}\text { (1) After you have finished LL } \\
\text { modules (1), use your MD and } \\
\text { search the Internet for software } \\
\text { tools to manage the EIS teams. } \\
\text { Requirements: you have to define } \\
\text { the team structure, types of teams, } \\
\text { team members, and manage their } \\
\text { availability. Please consider that } \\
\text { your teams consist of EIS Ltd. } \\
\text { members and external members, } \\
\text { working for (local) cooperation } \\
\text { partners or customers } \\
\text { (a) define your requirements } \\
\text { (b) search for available systems } \\
\text { [consider the budget given, see } \\
\text { EIS Ltd. description] } \\
\text { (c) compare the systems you } \\
\text { found (use function point } \\
\text { analysis) and the weight structure } \\
\text { given in the EIS Ltd. description. } \\
\text { (2) prepare a proposal for which } \\
\text { team management system should } \\
\text { be used (give a summary on the } \\
\text { system, emphasize the pros and } \\
\text { cons, give a short overview about } \\
\text { the system's functionalities, } \\
\text { explain the expected cost } \\
\text { structure (implementation cost, } \\
\text { operational cost), and formulate a } \\
\text { recommendation for the system } \\
\text { you want to use for EIS Ltd. }\end{array}$ & $\begin{array}{l}\text { (1) Use your LL starter kit } \\
\text { to tell the story about how } \\
\text { team management should } \\
\text { work for EIS Ltd. } \\
\text { Q: What is important for } \\
\text { managing a team? } \\
\text { Q: Which teams do you } \\
\text { have? } \\
\text { Q: Are they using the } \\
\text { same 'language' so they } \\
\text { can communicate with } \\
\text { each other? } \\
\text { Design the } \\
\text { structure' to manage the } \\
\text { company's teams. Discuss } \\
\text { your results with your } \\
\text { group members, prepare a } \\
1 \\
\text { explaining your design } \\
\text { and then start with ML (1) } \\
\text { and (2). }\end{array}$ \\
\hline $\begin{array}{l}\text { Project } \\
\text { management }\end{array}$ & $\begin{array}{l}\text { Management of all } \\
\text { customer (end.-to- } \\
\text { end) projects } \\
\text { (including project } \\
\text { structure, HR } \\
\text { strategy, resource } \\
\text { management, time } \\
\text { management, } \\
\text { meeting } \\
\text { management) }\end{array}$ & $\begin{array}{l}\text { (1) After you have finished the } \\
\text { LL modules (1), use your MD } \\
\text { and search the Internet for } \\
\text { possible project management } \\
\text { approaches (focus on } \\
\text { international approaches, since } \\
\text { your sample company is active } \\
\text { worldwide). } \\
\text { (2) Analyze what kind of project } \\
\text { management is needed for EIS } \\
\text { Ltd. (Consider that projects could } \\
\text { be internal ones or external ones, }\end{array}$ & $\begin{array}{l}\text { (1) Consider the following } \\
\text { situation: You have to } \\
\text { build a team for a new } \\
\text { project (at a customer's } \\
\text { site somewhere in Russia). } \\
\text { The team members should } \\
\text { consist of some of your } \\
\text { EIS colleagues, external } \\
\text { experts and customer's } \\
\text { employees. the typical } \\
\text { Consider the } \\
\text { difficulties you could face }\end{array}$ \\
\hline
\end{tabular}




\begin{tabular}{|c|c|c|c|}
\hline & & $\begin{array}{l}\text { directly on the customers' sites. } \\
\text { (3) Do an extended research on } \\
\text { project management systems } \\
\text { available (consider the EIS Ltd. } \\
\text { budget given) } \\
\text { (4) Choose five systems, which } \\
\text { may be used by EIS Ltd. and } \\
\text { compare these systems (use the } \\
\text { weight structure given in the EIS } \\
\text { Ltd. description. } \\
\text { (5) Prepare a proposal which } \\
\text { project management system } \\
\text { should be used (give a summary } \\
\text { on the system, emphasize pros } \\
\text { and cons, give a short overview } \\
\text { about the system's functionalities, } \\
\text { explain the expected cost } \\
\text { structure (implementation cost, } \\
\text { operational cost), and formulate a } \\
\text { recommendation for the system } \\
\text { you want to use for EIS Ltd. }\end{array}$ & $\begin{array}{l}\text { as a project leader. } \\
\text { Use your LL starter kit to } \\
\text { tell the story about your } \\
\text { difficulties. Share your } \\
\text { results with your group } \\
\text { members and prepare one } \\
(!) \text { story containing the } \\
\text { ideas of all group } \\
\text { members. } \\
\text { Present your results to } \\
\text { your instructor and the } \\
\text { other groups. }\end{array}$ \\
\hline $\begin{array}{l}\text { Change } \\
\text { management }\end{array}$ & $\begin{array}{l}\text { Management of } \\
\text { internal (change) } \\
\text { projects }\end{array}$ & $\begin{array}{l}\text { Related to the project } \\
\text { management topic; only internal } \\
\text { change projects have to be } \\
\text { considered. } \\
\text { (1) After you have finished LL } \\
\text { modules (1), use your MD and } \\
\text { find out what change } \\
\text { management is all about } \\
\text { Q: Why is change management } \\
\text { part of a company's strategic } \\
\text { planning approach? } \\
\text { Q: Consider your sample } \\
\text { company: what could be typical } \\
\text { change (management) topics? } \\
\text { (2) Consider how you want to } \\
\text { change the organizational } \\
\text { structure for EIS Ltd. } \\
\text { Q: What are the steps to be taken? } \\
\text { Q: How could the change project } \\
\text { be organized? } \\
\text { Q: Could there be resistance to } \\
\text { the change? From whom? Why? } \\
\text { Useful? Harmful? How to } \\
\text { handle? } \\
\text { (3) What kind of IT tool could } \\
\text { support you in managing the } \\
\text { change? }\end{array}$ & $\begin{array}{l}\text { (1) Consider the following } \\
\text { situation: Your company } \\
\text { has bought up another one } \\
\text { somewhere in Russia, and } \\
\text { you as a change manager } \\
\text { have to lead the project, } \\
\text { integrating all of the } \\
\text { business processes of the } \\
\text { other company in your } \\
\text { one. } \\
\text { Consider the typical } \\
\text { difficulties you could face } \\
\text { as a project leader. } \\
\text { Focus on the human } \\
\text { resource dimension. What } \\
\text { kind of resistance could be } \\
\text { a challenge for you? } \\
\text { What about your position } \\
\text { as a change manager? } \\
\text { Use your LL starter kit to } \\
\text { tell the story about your } \\
\text { difficulties. Share your } \\
\text { results with your group } \\
\text { members and prepare one } \\
\text { (!) story containing the } \\
\text { ideas of all the group } \\
\text { members. } \\
\text { Present your results to } \\
\text { your instructor and the } \\
\text { other groups. }\end{array}$ \\
\hline $\begin{array}{l}\text { Network } \\
\text { management }\end{array}$ & $\begin{array}{l}\text { Planning the } \\
\text { structure how to } \\
\text { cooperate with }\end{array}$ & $\begin{array}{l}\text { Related to the team management } \\
\text { and project management topics. } \\
\text { (1) After you have finished the }\end{array}$ & $\begin{array}{l}\text { (1) use your LL starter kit } \\
\text { and design the network } \\
\text { containing your company, }\end{array}$ \\
\hline
\end{tabular}




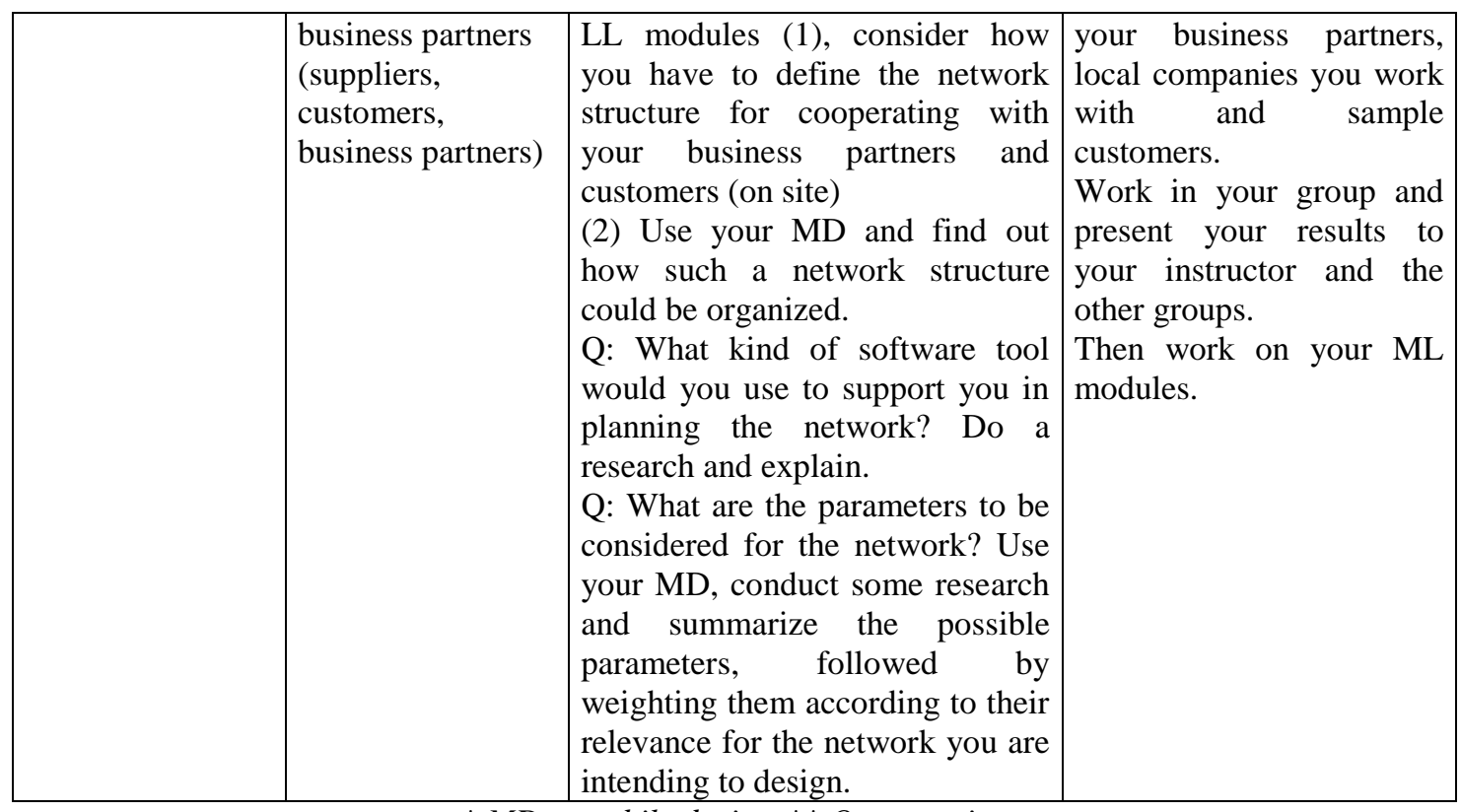

$* M D=$ mobile device $* * Q=$ question

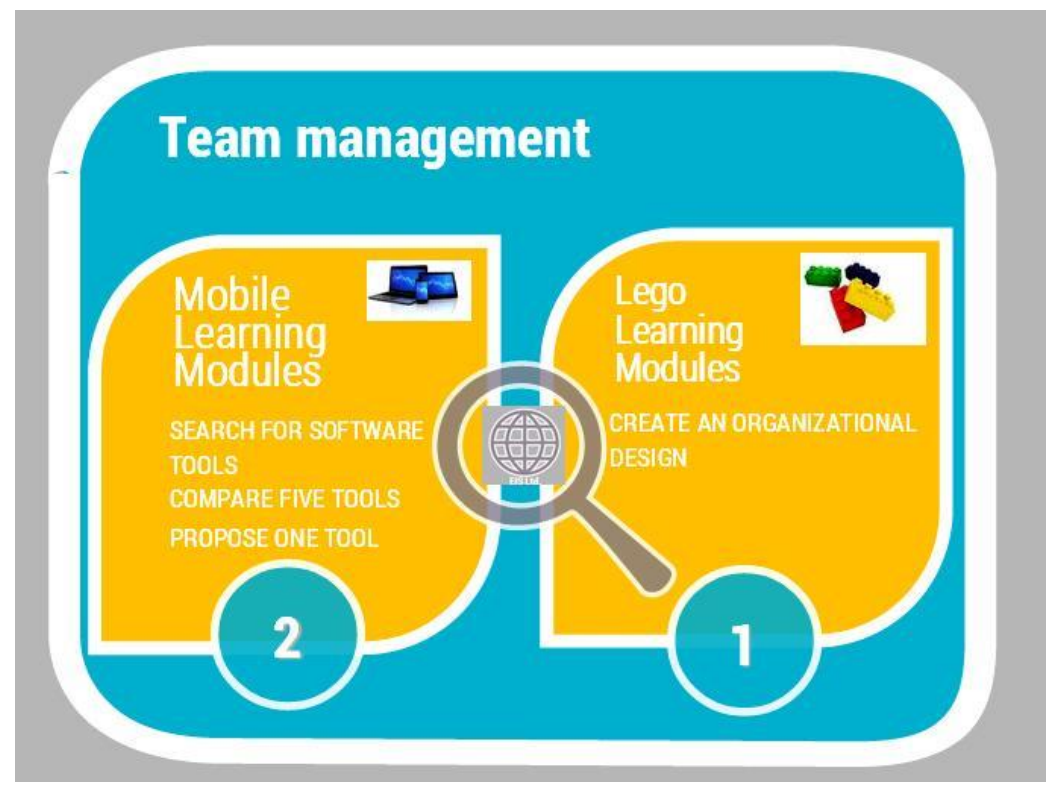

Figure 2. The ML-LL approach for the 'Team management' of EIS Ltd. 
Table 4. Software selection criteria

(student project results, after working on LL and ML modules)

\section{SOFTWARE SELECTION CRITERIA}

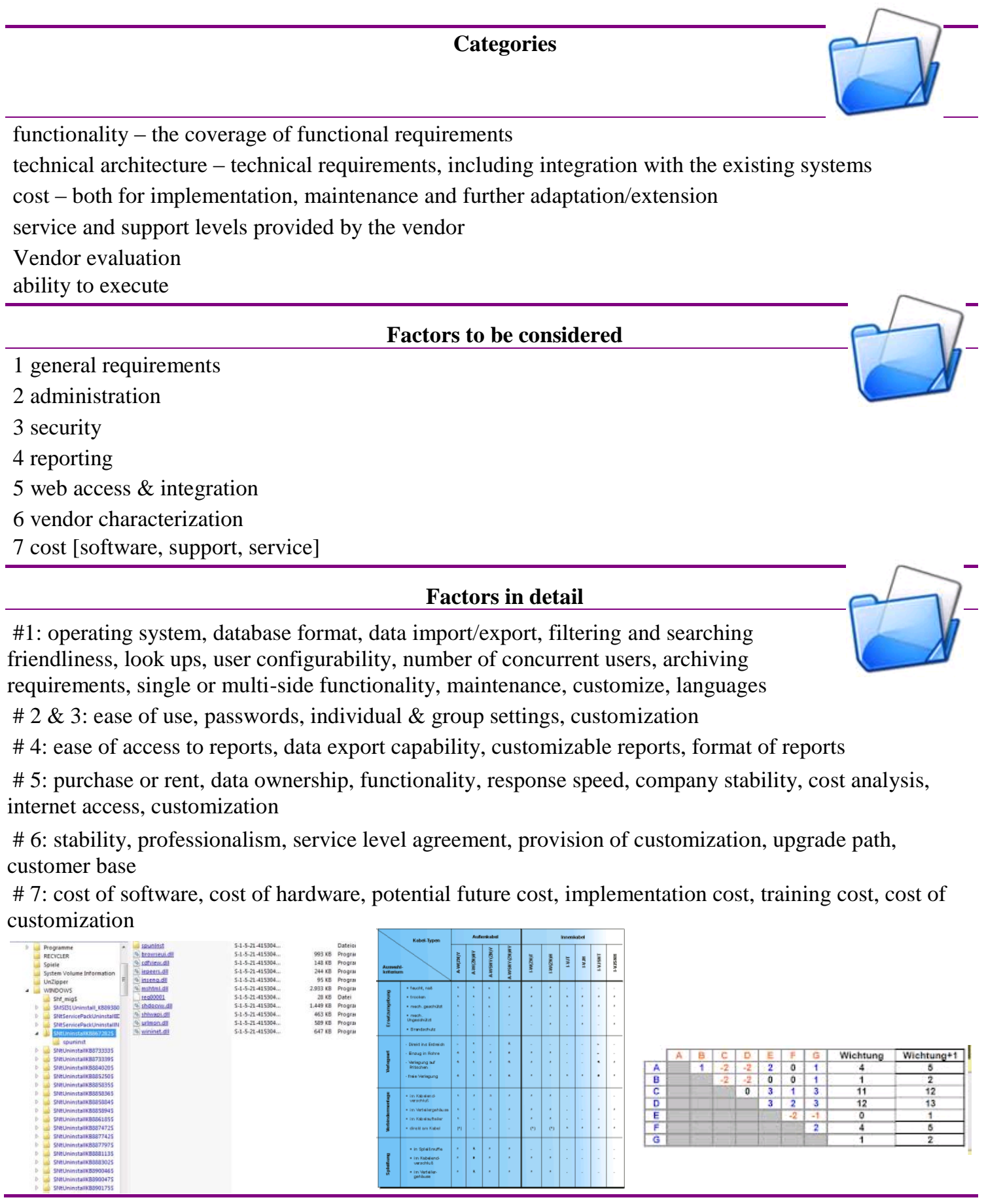




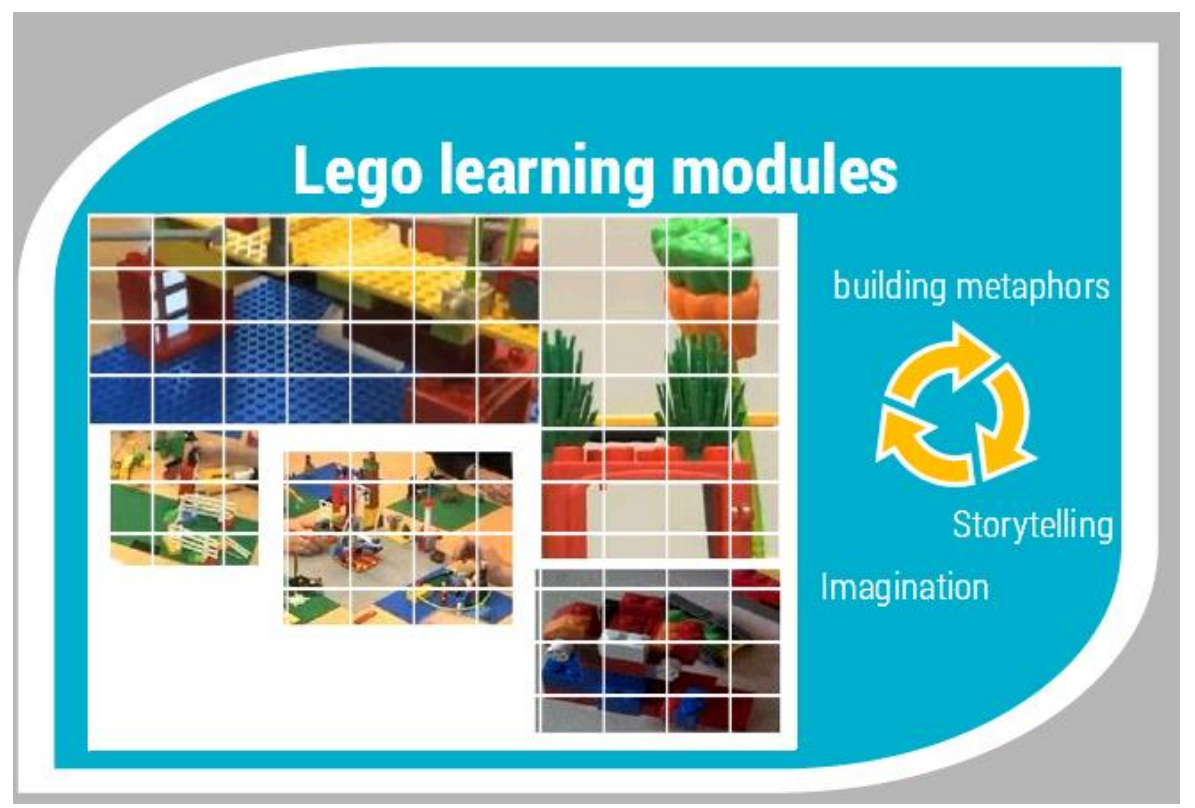

Figure 3. Lego bricks in use

(student project results, after working on LL and ML modules)

\section{Research Results}

All of the students used Google Plus functionalities in their groups and for communicating with the instructor. An ad hoc group-to-group communication was not established by the students during the semester. Online office hours of the instructor using Google Plus hangouts were used frequently (at least twice a week) by each group. The instructor created a Google Plus circle for the EIS course, sharing course relevant information and materials. Students were active on Google Plus at least once a day. In comparison to that, when the instructor used the blackboard as a communication tool for the course in the past, students were active in the system every third day on average, with lots of students not active throughout the whole semester. With the Google Plus option in use, the instructor could benefit from the students activities on social media, Google Plus was used frequently for course related issues and private ones as well. In comparison to the study conducted in 2011, where the Google Plus usage rate was 0.78 , with a course relation of factor 5.2, in the EIS course the Google Plus usage rate was 0.92 , with a course relation of factor 8.0 . Having $97 \%$ of all students working with their mobile devices on social networks in 2011, nearly all of them, $99.6 \%$, used social networks for the EIS course.

Similar to the study conducted in 2012 (integrating Lego learning elements in higher education) for this study the instructor focused on the instructor dimension, which means (1) teaching, (2) instructor-student interaction, and the student learning. For the analysis the dimensions (a) quality, (b) participation, (c) grade and (d) students were considered. Table 5 summarizes the research results.

Considering mobile learning modules the combination of ML and LL had a positive impact on student performance. Usage of social networks increased (97\% to 99.6\%), usage of mobile devices for working on projects and assignments increased (80.6\% to $97.8 \%$ and $90.2 \%$ to $98.7 \%$ ), and the student willingness to test software for their projects increased as well from $52.5 \%$ to $70.8 \%$. 
Considering the Lego Learning modules (LLM), the students attendance rate, compared to the study conducted in 2012, increased from $92 \%$ to $98.7 \%$ (the results sorted by student type are shown in table 5). Project quality for students with a cumulative grade between 3.00 and above improved from 95/100 to 99/100, while the project quality for those having a cumulative grade between 2.00 and 3.00 remained unchanged at the 90/100 level and the performance of students with a cumulative grade below 2.00 decreased from 75/100 to 67/100. These results revealed that the combination of ML and LL modules in course design has a positive impact on students with an excellent performance, a minor impact on students with an average performance and a negative one on partly unsuccessful students with an average under 2.00. A reason for that could be that the ML and LL combination causes more experiences, challenges, and knowledge for students but also more work in comparison to other courses offering no ML or LL modules and less successful students resist more than others trying the innovative and creative course elements. The overall course result before ML/LL and after ML/LL integration showed that the average result increased by 0.5 to 0.83 , the best result by 0.7 to 0.98 and the weakest result by 0.26 to 0.56 . Although the results for students with a performance below 2.00 decreased for Lego learning modules, the overall results for those students significantly increased from 0.30 by 0.26 to 0.56 .

Table 5. Research results

\begin{tabular}{|c|c|c|}
\hline \multicolumn{3}{|c|}{ Mobile Learning modules (MLM) } \\
\hline & 2011 (previous study*) & 2013 (EIS course $* * *)$ \\
\hline Google Plus usage rate & 0.78 & 0.92 \\
\hline Course relation & Factor 5.2 & Factor 8.0 \\
\hline Students using social networks & $97.0 \%$ & $99.6 \%$ \\
\hline $\begin{array}{l}\text { Use of mobile devices for } \\
\text { working on projects (group) }\end{array}$ & $80.6 \%$ & $97.8 \%$ \\
\hline $\begin{array}{l}\text { Use of mobile devices for } \\
\text { working on assignments (student) }\end{array}$ & $90.2 \%$ & $98.7 \%$ \\
\hline $\begin{array}{l}\text { Use of mobile devices to test } \\
\text { software }\end{array}$ & $52.5 \%$ & $70.8 \%$ \\
\hline \multicolumn{3}{|c|}{$\begin{array}{l}\text { Lego learning modules (LLM) } \\
\end{array}$} \\
\hline \multicolumn{3}{|l|}{ Attendance } \\
\hline & 2012 (previous study**) & $2013($ EIS course $* * *)$ \\
\hline Attendance rate & $92 \%$ & $98.7 \%$ \\
\hline $\begin{array}{l}\text { Attendance rate/background } \\
\text { Business } \\
\text { Engineering }\end{array}$ & $\begin{array}{l}\text { Before } L L M \text { result }+10 \% \\
\text { Before } L L M \text { result }+32 \%\end{array}$ & $\begin{array}{l}2012 \text { result }+12 \% \\
2012 \text { result }+0.9 \%\end{array}$ \\
\hline \multicolumn{3}{|l|}{ Project quality } \\
\hline Student type & 2012 (previous study**) & 2013 (EIS course $* * *)$ \\
\hline Cumulative grade 3.00 or above & $95 / 100$ & $99 / 100$ \\
\hline $\begin{array}{l}\text { Cumulative grade between } 2.00 \\
\text { and } 3.00\end{array}$ & $90 / 100$ & $90 / 100$ \\
\hline Cumulative grade below 2.00 & $75 / 100$ & $67 / 100$ \\
\hline \multicolumn{3}{|l|}{ Overall course results } \\
\hline & Before ML and LL & With ML and LL \\
\hline Average result & 0.78 & 0.83 \\
\hline Best result & 0.91 & 0.98 \\
\hline Weakest result & 0.30 & 0.56 \\
\hline
\end{tabular}




\section{Conclusions}

Students are a university's customers in terms of educational services. Making these students satisfied and successful is one premise that instructors have to follow. Creative learning elements in education could improve teaching, student-instructor interaction, student learning, and course results. Creative learning modules could focus on different dimensions to motivate students and prepare them for the further business life.

In this study, both mobile learning modules (MLM) as well as Lego learning modules (LLM) were implemented for a bachelor's degree course on enterprise information systems to measure the overall outcome, in comparison to previous studies where MLM and LLM were implemented separately. To motivate students to work on course related topics and to give them a business relevant example, a sample company, the EIS Ltd., was 'founded' and students had to work on improving the company's performance. The results revealed that there is a positive relationship for an MLM and LLM combination, mainly for students with a performance between 2.00 and 3.00. The better the students cumulative grade, the better their response rate on creative learning elements.

In a further project the combination of mobile learning modules and Lego learning modules should be improved to get better results for all students, but mainly to improve the performance of those students having cumulative results between 2.00 and 3.00 that, according to this study, were only partly affected by the creative learning elements implemented.

\section{References}

[1] A. Erkollar and B. Oberer, "Anytime. Everywhere. Mobile Learning in Higher Education", Computer Applications for Database, Education, and Ubiquitous Computing, (2012), pp. 31-37.

[2] A. Erkollar and B. Oberer, "Trends in Social Media Application: The Potential of Google+ for Education Shown in the Example of a Bachelor's Degree Course on Marketing", Communications in Computer in Information Science, vol. 257, (2011), pp. 569-578.

[3] B. Oberer, "Back to the Stone Age. Creative Education Shown in the Example of a Management Information Systems (MIS) course", International Conference on Creative Education, (2013).

[4] Executive discovery llc., The Science of Lego Serious Play, Enfield, (2002).

[5] D. Keegan, G. Dismihok, N. Mileva and T. Rekkedal, "The role of mobile learning in European education", Work Package 4, 227828-CP-1-2006-1-IE-MINERVA-M, European Commission, (2006).

[6] N. M. Rao, C. Sasidhar and V. S. Kumar, "Cloud Computing Through Mobile Learning", International Journal of Advanced Computer Science and Applications, vol. 1, no. 6, (2010), pp. $42-43$.

[7] J. Hylen, United Nations Educational, Scientific and Cultural Organization (UNESCO), Turning on Mobile Learning in Europe. Illustrative Initiatives and Policy Implications, UNESCO Working Paper Series on Mobile Learning, France, (2012).

[8] M. Sarrab, L. Elgamel and H. Aldabbas, "Mobile Learning (M-Learning) and Educational Environments", International Journal of Distributed and Parallel Systems, vol. 3, no. 4, (2012), pp. 31-28.

[9] G. Dykes and H. Knight, United Nations Educational, Scientific and Cultural Organization (UNESCO). Mobile Learning for Teachers in Europe. Exploring the Potential of Mobile Technologies to Support Teachers and Improve Practices', UNESCO Working Paper Series on Mobile Learning, France, (2012).

[10] R. A. Beghetto and J. C. Kaufman, "Fundamentals of Creativity, Creativity now!", vol. 70, no. 5, (2013), pp. $10-15$.

[11] R. A. Beghetto, "Creativity in the classroom", in: J. C. Kaufman and R. J. Sternberg (Eds.), The Cambridge handbook of creativity, Cambridge: Cambridge University Press, (2010), pp. 447-466.

[12] B. A. Hennessey and T. M. Amabile, "Creativity", Annual Review of Psychology, vol. 61, (2010), pp. 569598.

[13] L. Zhang, Z. Han and Q. Gao, "Empirical Study on the Student Satisfaction Index in Higher Education", International Journal of Business and Management, vol. 3, no. 9, (2008), pp. 46-51. 


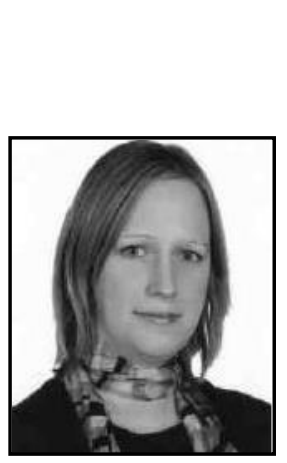

Author

Birgit Oberer is a member of the Faculty of Engineering and Natural Sciences at Kadir Has University. Currently, her academic interests are management information systems, eGovernment, and creative education. She actively takes part in a number of international networks and task forces on Management and IT and is a member of editorial (reviewer) boards for international journals. 
International Journal of Education and Learning Vol. 2, No. 2 (2013) 